\title{
Additions to the Estonian Bryoflora 2019-2021: Liverworts and Mosses
}

\author{
Kai Vellak $^{1,2}$, Loore Ehrlich ${ }^{3}$, Mare Leis ${ }^{4}$, Tiiu Kupper ${ }^{1,2}$, Leiti Kannukene ${ }^{5}$, \\ Nele Ingerpuu ${ }^{1}$ \\ ${ }^{1}$ University of Tartu, Institute of Ecology and Earth Sciences, J. Liivi Str. 2, Tartu 50409; E-mail: kai.vellak@ut.ee \\ ${ }^{2}$ University of Tartu, Natural History Museum, Vanemuise 46, Tartu 51014 \\ ${ }^{3}$ Estonian Museum of Natural History, Lai 29A, Tallinn 10133 \\ ${ }^{4}$ Estonian University of Life Sciences, Institute of Agricultural and Environmental Sciences, Kreutzwaldi 5, Tartu 51014 \\ ${ }^{5}$ Tallinn Botanic Garden, Kloostrimetsa tee 52, Tallinn 11913
}

\begin{abstract}
Six species and one subspecies new for Estonia have been found during recent fieldworks. In addition, three varieties from our bryoflora are now accepted as species and so the number of species in Estonian bryoflora is currently 611 . Voucher specimens are selected for all new species reported here. Most of the species are included preliminarily into category Data Deficient (DD) according to IUCN structure. Besides this, updated proposals for threat categories are given for four noteworthy bryophytes, which localities were inspected in 2019-2020. Estonian names are given to all new species.
\end{abstract}

Keywords: IUCN category, new taxa for Estonia, voucher specimen

\section{INTRODUCTION}

In 1860, the first list of bryophytes of Estonian territory was released including 301 species (Girgensohn, 1860). Since then, the list has been revised from time to time (e.g., Malta, 1930; Ingerpuu et al., 1994; Vellak et al., 2015), and during 160 years the number of known species has doubled (Fig. 1). In the last two years, nine new species have been added to Estonian bryoflora and thus the number of species has risen to 611 .

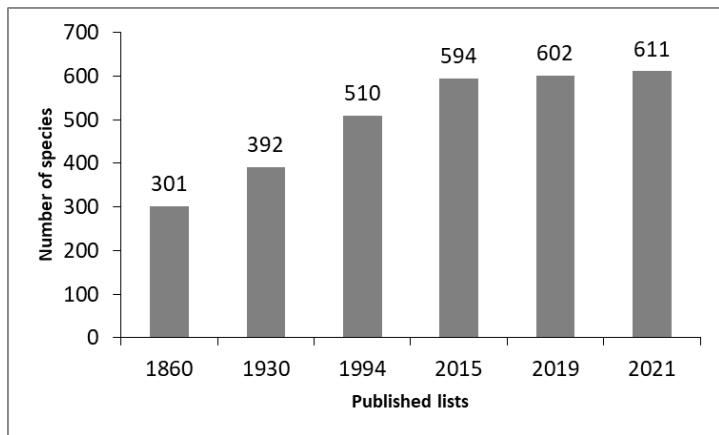

Fig. 1. Numbers of bryophyte species in Estonia in period 1860-2021, based on published sources: 1860 - Girgensohn (1860); 1930 - liverworts, Malta \& Strautmanis (1926), mosses Malta (1930); 1994 - Ingerpuu et al. (1994); 2015 - Vellak et al. (2015); 2019 - Vellak et al. (2019).
Here, we report habitat, distributional and IUCN assessment data on six species and one subspecies that are reported first time for Estonia and on three species that were known earlier at variety level in Estonia. In addition, we provide revised IUCN evaluations for four species.

The flora of a particular country is in constant change. Some species may get lost; others may arrive from shorter or greater distances. The change may also come from taxonomical research including revision of herbarium specimens.

\section{MATERIAL \& METHODS}

All Estonian herbaria with bryophyte collections (TAA; TAM; TALL; TU) were involved in this study for clarifying current distribution and set the valid voucher specimens for new taxa and combinations. The threats on species were evaluated according to IUCN assessment rules (IUCN Standards and Petitions Subcommittee, 2017). Proposals for the IUCN categories are presented both for all new species and additionally for four species that were included in the project "Inventory of localities of Estonian threatened bryophyte species for planning their protection" (2019-2020, financed by EEIC project no. 16026). Consensus on new Estonian names was first achieved by the authors. Then, names were approved by the Committee of Estonian 
Botanical Terminology. The voucher specimens of taxa new for Estonia are deposited in TU, TAA and TAM.

\section{RESULTS AND DISCUSSION}

\section{New taxa for Estonia}

All new species reported here, are proposed to be included in Data Deficiency (DD) category until their actual distribution and threats in Estonia will be known.

DICRANUM LAEVIDENS R.S. Williams [põhja-kaksikhammas]

Voucher specimen: TAA5007182, Viljandi Co., Viljandi Comm., Järtsaare, in bog, $40 \mathrm{~m}$ away from the peat excavation area $\left(58.5724^{\circ} \mathrm{N}\right.$; $\left.25.8826^{\circ} \mathrm{E}\right)$, leg. M. Leis, 16 July 2019, det. M. Leis, 26 July 2019, ver. L. Hedenäs, 30 Sep 2019. Duplicate TAA5007183.

Dicranum laevidens has exclusively Nordic distribution in Europe (Hodgetts \& Lockhart, 2020), where it grows in fens in drier microhabitats (Hedenäs \& Bisang, 2004). Estonian specimen was collected at the edge of a drained bog, nearby a peat extraction area.

EnTOSTHOdON MUHLENBERGiI Fife [Mühlenbergi loodhellik]

Voucher specimen: TU153671a, Saare Co., Saaremaa Comm., Kaugatoma village, Lõu open alvar, on soil $\left(58.1213^{\circ} \mathrm{N} ; 22.2012^{\circ} \mathrm{E}\right)$, leg. N. Ingerpuu, T. Kupper, 24 May 2020, det. N. Ingerpuu, 29 May 2020. Duplicate TU153671b.

Entosthodon muhlenbergii is widely distributed in the world having locations even in the southern hemisphere. Still, the species seems to be quite rare everywhere, and therefore the IUCN category of this species in Europe is near threatened (NT; Hodgetts \& Lockhart, 2020). The species grows in Europe on open calcareous grasslands; in Sweden it is typical in alvar areas (Hallingbäck et al., 2006). All species of the genus Entosthodon belong to life strategy group of annual shuttle species (Dierßen, 2001). Such species pass their life cycle quite fast and might be not visible in unsuitable weather conditions. This can explain why it is rarely found in their habitats. This species was found in spring 2020 from two alvars in Saaremaa Island (Lõu and Atla) which have been studied also in earlier years for several times. The weather conditions of this spring were probably suitable for the species to germinate.

MARCHANTIA QUADRATA SUBSP. HYPERBOREA (R.M. Schust.) Borovich. [lubihelvik]

Voucher specimen: TU173619, Saare Co., Saaremaa Comm., Ohtja sedge fen, on wet ground in the shade of sedge tussock $\left(58.4389^{\circ} \mathrm{N}\right.$; $\left.22.2975^{\circ} \mathrm{E}\right)$, leg. K. Vellak, M. Müür, 17 June 2020, det. N. Ingerpuu, 25 June 2020.

The subspecies was described in 1985 by Schuster as Preissia quadrata subsp. hyperborea Schust. (Schuster, 1985). Later the species was included in genus Marchantia (Long et al., 2016), and the subspecies was accepted as Marchantia quadrata subsp. hyperborean (R.M.Schust.) Borovich. (Sokolova et al., 2017). This subspecies was described from Greenland (Schuster, 1985), and has Holarctic distribution. It grows on thin soil on humid calcareous rocks (Damsholt, 2002), but has also been found on peat soil (Konstantinova \& Savchenko, 2018). In Europe it is known only in Scandinavia and arctic Russia (Hodgetts \& Lockhart, 2020).

Plagiothecium longisetum Lindb. [harjakas põikkupar]

Voucher specimen: TU151281, Ida-Viru Co., Tudu Comm., 12 Aug 1996, mixed forest, ca 1 $\mathrm{km}$ from Tudu, on a bolder $\left(59.1926^{\circ} \mathrm{N} 26.8574^{\circ}\right.$ E), leg. M. Leis, 18 Aug 1996, det. G. J. Wolski, 13 Aug 2016.

Plagiothecium longisetum has been long treated as a synonym of $P$. nemorale (Mitt.) A. Jaeger. Recent molecular and morphological studies suggested it to be a separate species (Wolski \& Nowicka-Krawczyk, 2020), where also 116 herbarium specimens of $P$. nemorale-group from Estonia were included and one of them was verified as $P$. longisetum.

Plagiothecium angusticellum G.J. Wolski \& P. Nowicka-Krawczyk [kitsarakuline põikkupar] Voucher specimen: TAA5004954, Viljandi Co, Viljandi Comm., Loodi NP, Heimtali village, in nemoral forest on a foot of Acer platanoides $\left(58.2922^{\circ} \mathrm{N}\right.$; $\left.25.5398^{\circ} \mathrm{E}\right)$, leg. M. Leis, 17 June 1996, det. G. J. Wolsky, 12 March 2020.

Plagiothecium angusticellum is a newly described species, separated from $P$. nemorale s.1. (Wolski $\&$ Nowicka-Krawczyk, 2020). This species occurs on soil, stones or tree trunks in nemoral 
forests. Its current distribution is restricted to Central Europe. Beside Estonia, it is known also in our southern neighbour countries Latvia and Lithuania (Wolski \& Nowicka-Krawczyk, 2020).

Schistidium DUPRETII (Thér.) W.A. Weber [Dupret' lõhistanukas]

Voucher specimen: TAM0065133, Harju Co., Viimsi Comm., Viimsi peninsula, $1 \mathrm{~km}$ E from Haabneeme lighthouse, spruce forest on clint, (approx. coordinates: $59.5166^{\circ} \mathrm{N} ; 24.8394^{\circ} \mathrm{E}$ ), leg. H. Aasamaa, 17 Nov 1987, det. L. Ehrlich, 11 Nov 2020, ver. N. Ingerpuu, K. Vellak, M. Leis, 16 March 2021.

Schistidium dupretii is characteristic to the mountainous regions in Northern Hemisphere. It is common in Central and Northern Europe and in North America, where it grows on dry exposed calcareous rocks (Hallingbäck et al., 2008). In Europe, it is evaluated as LC, but in several European countries it is evaluated as DD (Hodgetts \& Lockhart, 2020).

Solenostoma obovatum (Nees) C. Massal. [jõgiümarlehik]

Voucher specimen: TAA5008078, Jõgeva Co., Mustvee Comm., River Avijõgi, riverside near Mulgi veski $\left(58.9705^{\circ} \mathrm{N} ; 27.0143^{\circ} \mathrm{E}\right)$, leg. S. Vilbaste, 09 July 2019, det. N. A. Konstantinova, 26 Feb 2020. Duplicate in TU (TU173574).

This species is widespread but quite rare in Europe and is considered to be a boreal montane species (Damsoholt, 2002). Solenostoma obovatum grows on rocks and on soil nearby streams, but can also be submerged (Glime, 2020). Still, several new records have been discovered recently over Europe (Ştefănuț \& Goia, 2012; Vieira et al., 2017), and therefore it is evaluated as LC in Europe (Hodgetts \& Lockhart, 2020).

\section{Species that were formerly varieties}

DNA studies have become more and more prominent in the taxonomical studies of bryophytes, and recently several previous varieties are proved to be separate species. While studying Hypnum cupressiforme-complex, it became evident that $H$. resupinatum known also as $H$. cupressiforme var. resupinatum, is distinct from $H$. cupressiforme s.str. according to DNA sequence data, and although they may grow as mixtures, they are now considered as separate species (Schlesak et al., 2018). H. resupinatum Taylor [käändulmik] is known from Estonia since 2017 as $H$. cupressiforme var. resupinatum (Vellak et al., 2017), with one locality. Since then, six more localities were found, among them two identified from older herbarium materials (eElurikkus), the first record dates back to 1974 . This species is sporadically distributed in Estonia according to the recent data and is estimated here as Least Concerned (LC), since it has localities both in human influenced and natural habitats and no threats were noticed. This species grows in Estonia mainly on trunks of coniferous and deciduous trees, but also on boulders and snags. Hypnum cupressiforme inhabits similar substrates in Estonia.

Polytrichum perigoniale Michx. [kõnnu-karusammall was described as a species already in 1803 by A. Michxaux, but was later united with $P$. commune as a variety. Recent molecular studies have suggested it to be a distinct species rather than a variety of $P$. commune (e.g., Kariyawasam et al., 2021). In Estonia this species is known since 1853 and in 1994 it was evaluated as rare in Estonia (Ingerpuu et al., 1994). More than ten localities have been found recently and it is now sporadically distributed in Estonia. No threats to this species have been noticed, and therefore according to the IUCN criteria $P$. perigoniale is evaluated here as LC. It occupies similar habitats as $P$. commune, but has been found in more open sites on peat soil.

Tortella densa (Lorenz \& Molendo) Crundw. \& Nyholm [tihe keerdsammal] was separated from T. inclinata based on morphological characteristics in 1962 (Crundwell \& Nyholm, 1962). For Estonia this species was reported at variety level in 2009 with one locality on Saaremaa Island (Vellak et al., 2009). In 2021, this species has already 15 localities in Estonia. The habitats are exclusively on alvars of West Estonia and on islands, the most eastward locality is in Jõgeva County where the species grows on a small alvar remnant. Alvars are listed among important European habitats, but are in great decline (Krauss et al. 2010). Although this species is sparsely distributed in Estonia, it is evaluated as Near Threatened (NT), because of continuing decline of habitat quality. 


\section{Revised IUCN Red List categories for selected species}

The actual distribution and status of 16 bryophytes, rare in Estonia or valuable at European level were inventoried in 2019-2020. Four inventoried species - Herzogiella turfacea, Hamatocaulis lapponicus, Meesia longisteta and Orthotrichum rogeri - belong to the Habitat Directive Annex II (Commission of the European Communities, 2003). Sphagnum mosses are included to the Annex V at genus level. Eight Sphagnum species (S. austinii, S.affine, S. auriculatum, S. jensenii, S. inundatum, S. platyphyllum) were included to this project. According to the inventory four studied species were re-evaluated against their previous IUCN category assessment (Table 1).

Orthotrichum rogeri Brid. was evaluated as Data Deficient (DD) in the last red list (Ingerpuu et al., 2018) since the species had been not found again from its only known locality. Inspecting this locality in 2020 we found one small patch on Salix caprea trunk. Orthotrichum rogeri belongs to the Appendix II of EU Habitat Directive, but it has been ascertained that the species favours areas with human influence and seems to expand its distribution in Europe (Lüth, 2010; Bosanquet, 2015). We see no threats to this species and since it is difficult to identify outdoors, we suppose that it might have more localities. Here, O. rogeri is evaluated as Vulnerable (VU, criteria D2) in Estonia.

Sphagnum auriculatum Schimp. was evaluated as Endangered (EN) in 2018. Last inventories added some new records, and this species has now five recent localities, at some localities the species occurs abundantly. No obvious threats for its habitats were noticed during inventories and thus the species is evaluated as VU (criteria B2ab(iii); D2).

The state of two other inspected Sphagnum species is more critical, since they were not found during the recent inventories. Sphagnum jense$n i i \mathrm{H}$. Lindb. has only two old localities from the 50-ties and it might be vanished from Estonian bryoflora. However, according to Estonian conventional rules about the time limit for regionally extinct species, it should be placed to the category DD. Sphagnum molle Sull. was recorded first time in Estonia in 1997 from two localities, but during the last inventory in 2020, we did not find this species again, so we evaluated it as
DD. The former identifications were also checked and they were found to be correct.

Table 1. List of species with changes in IUCN categories

\begin{tabular}{lcc}
\hline Species & $\mathbf{2 0 1 8}$ & $\mathbf{2 0 2 1}$ \\
\hline Orthotrichum rogeri & $\mathrm{DD}$ & $\mathrm{VU}$ \\
Sphagnum auriculatum & $\mathrm{EN}$ & $\mathrm{VU}$ \\
Sphagnum jensenii & $\mathrm{VU}$ & $\mathrm{DD}$ \\
Sphagnum molle & $\mathrm{EN}$ & $\mathrm{DD}$ \\
\hline
\end{tabular}

\section{ACKNOWLEDGEMENTS}

The study was supported by Estonian Research Council (PRG609 and RPG1121), the European Regional Development Fund (Centre of Excellence EcolChange), Estonian Environmental Investment Centre (EEIC project no. 16026), the Ministry of Education and Research (KOGUTU256, 8-2/T9042PKBJ). The authors are thankful to G. J. Wolski, N. A. Konstantinova, and L. Hedenäs for the help in species identifications. We are thankful for the three reviewers for valuable comments.

\section{REFERENCES}

Bosanquet, S. D. S. 2015. Orthotrichum rogeri Brid. In England, new to Britain. Journal of Bryology 37(4): 329-331.

Commission of the European Communities 2003. Council directive 92/43/EEC of 21 May 1992 on the conservation of natural habitats and of wild fauna and flora. As amended by the Accession Act of Austria, Finland and Sweden (1995) and the Accession Act of the Czech Republic, the Republic of Estonia, the Republic of Cyprus, the Republic of Latvia, the Republic of Lithuania, the Republic of Hungary, the Republic of Malta, the Republic of Poland, the Republic of Slovenia and the Slovak Republic (2003). Official Journal of the European Union L 23633 23.9.2003. Brussels. European Commission 1992/95/2003.< https://eur-lex.europa. eu/eli/dir/1992/43/oj>. (Accessed 05.04.2021).

Crundwell, A. C. \& Nyholm, E. 1962. Notes on the genus Tortella. I. T. inclinata, T. densa, T. flavovirens and T. glareicola. Transactions of the British Bryological Society 4: 187-193.

Damsholt, K. 2002. Illustrated flora of Nordic liverworts and hornworts. Nordic Bryological Society, Lund. $840 \mathrm{pp}$.

Dierßen, K. 2001. Distribution, ecological amplitude and phytosociological characterization of European bryophytes. Bryophytorum Bibliotheca 56: 3-289. 
Girgensohn, G. K. 1860. Naturgeschichte der Laubund Lebermoose Liv-, Ehst- und Kurlands. Archiv für die Naturkunde Liv-, Ehst- und Kurlands 2(2): $1-488$.

Glime, J. M. 2020. Aquatic and Wetland habitats. In: Glime, J. M. Bryophyte Ecology. Volume 4. Habitat and Role. Ebook sponsored by Michigan Technological University and the International Association of Bryologists. Last updated 21 July 2020 and available at $<\mathrm{http}: / /$ digitalcommons.mtu. edu/bryophyte-ecology/>. (Accessed 05.04.2021).

Hallingbäck, T., Lönell, N., Weibull, H., Hedenäs, L. \& von Knorring, P. 2006. Nationalnyckeln till Sveriges flora och fauna. Bladmossor: Sköldmossor blåmossor. Bryophyta: Buxbaumia - Leucobryum. ArtDatabanken, SLU, Uppsala. 416 pp.

Hallingbäck, T., Lönell, N., Weibull, H., von Knorring, P., Korotynska, M., Reisborg, C. \& Birgesson, M. 2008. Nationalnyckeln till Sveriges flora och fauna. Bladmossor: Kompaktmossor - kapmossor. Bryophyta: Anoectangium - Orthodontium. ArtDatabanken, SLU, Uppsala. 504 pp.

Hedenäs, L. \& Bisang, I. 2004. Key to European Dicranum species. Herzogia 17: 179-197.

Hodgetts, N. \& Lockhart, N. 2020. Checklist and country status of European bryophytes - Update 2020. Irish Wildife Manuals 123: 1-95.

Ingerpuu, N., Kalda, A., Kannukene, L., Krall, H., Leis, M. \& Vellak, K. 1994. Eesti sammalde nimestik. Abiks Loodusevaatlejale 94: 5-175. (In Estonian).

IUCN Standards and Petitions Subcommittee 2017. Guidelines for Application of IUCN Red list criteria. Version 13. Prepared by the Standards and Petitions Subcommittee. http://www.iucnredlist. org/documnets/redListGuidelines.pdf

Kariyawasam, I. U., Price, M. J., Bell, N. E., Long, D. G., Mill, R. R. \& Hyvönen, J. 2021. Unearthing a lectotype for Polytrichum commune Hedw. (Bryophyta, Polytrichaceae). Taxon. https://doi. org/10.1002/tax.12444

Konstantinova, N. \& Savchenko, A. 2018. Contribution to the bryophyte flora of Svalbard: hepatics of Barents Island. Folia Cryptogamica Estonica 55: 105-115.

Krauss, J., Bommarco, R., Guardiola, M., Heikkinen, R. K., Helm, A,, Kuussaari, M., Lindborg, R., Ockinger, E., Pärtel, M., Pino, J., Pöyry, J., Raatikainen, K. M., Sang, A., Stefanescu, C., Teder, T., Zobel, M. \& Steffan-Dewenter, I. 2010. Habitat fragmentation causes immediate and time-delayed biodiversity loss at different trophic levels. Ecology Letters 13(5): 597-605.

Long, D. G., Forrest, L. L., Villarreal, J. C. \& Crandall-Stotler, B. J. 2016. Taxonomic changes in Marchantiaceae, Corsiniaceae and Cleveaceae (Marchantiidae, Marchantiophyta) Phytotaxa 252 (1): $77-80$.
Lüth, M. 2010. Ökologie and Vergesellschaftung von Orthothrichum rogeri. Herzogia 23: 165-180.

Malta, N. 1930. Übersicht der Moosflora des Ostbaltischen Gebietes. II. Laubmoose (Andreaeales et Bryales). Acta Horti Bot. Univ. Latviensis 5(1/3): 75-104.

Malta, N. \& Strautmanis, J. 1926. Übersicht der Moosflora des Ostbaltischen Gebietes. I. Acta Horti Bot. Univ. Latviensis 1: 115-142.

Schlesak, S., Hedenäs, L., Nebel, M. \& Quandt, D. 2018. Cleaning a taxonomic dustbin: placing the European Hypnum species in a phylogenetic context! Bryophyte Diversity and Evolution 40(2): 037-054.

Schuster, R. M. 1985. Some new taxa of Hepaticae. Phytologia 57(6): 408-414.

Sokolova, I. V., Kapustin, D. A., Davydov, D. A., Borovichev, E. A. \& Potemkin, A. D. 2017. Cryptogamic nomenclatural notes. 1. Novosti Sistematiki Nizaikh Rastenii 51: 281-285.

Ştefănuț, S. \& Goia, I. 2012. Checklist and red list of bryophytes of Romania. Nova Hedwigia 95(1-2): 59-104.

Vellak, K., Callejo, R. C., Ingerpuu, N., Leis, M., Ehrlich, L. \& Kupper, T. 2019. Additions and amendments to the list of Estonian bryophytes. Folia Cryptogamica Estonica 56: 1-5. https://doi. org/10.12697/fce.2019.56.01

Vellak, K., Ingerpuu, N., During, H., Flatberg, K. I., Leis, M., Ehrlich, L., Kannukene, L. \& Kupper, T. 2017. New Estonian records: mosses. Folia Cryptogamica Estonica 54: 143-145. https://doi. org/10.12697/fce.2017.54.17

Vellak, K., Ingerpuu, N., Kannukene, L., Leis, M. \& Kullman, B. 2009. New Estonian records and amendments. Liverworts and mosses. Pezizales (Ascomycetes). Folia Cryptogamica Estonica 45: 91-93. https://ojs.utlib.ee/index.php/FCE/ article/view/13677

Vellak, K., Ingerpuu, N., Leis, M. \& Ehrlich, L. 2015. Annotated checklist of Estonian bryophytes. Folia Cryptogamica Estonica 52: 109-127. https://doi. org/ 10.12697 /fce.2015.52.14

Vieira, C., Sergio, C. \& Seneca, A. 2007. Some remarkable bryophytes from the aquatic habitats in northwestern Portugal. Cryptogamie, Bryologie 28(3): 281-287.

Wolski, G. J. \& Nowicka-Krawczyk, P. 2020. Resurrection of the Plagiothecium longisetum Lindb. and proposal of the new species. $-P$. angusticellum. PLOS One. https://doi.org./10.1371/journal. pone.0230237 